\title{
レーザー照射による「極興奮の法則」に対する抑制効果
}

\author{
小松 光昭 ${ }^{1}$, 松田 芳樹 ${ }^{2}$, 石井 良夫 ${ }^{1}$, 木暮 信一 ${ }^{2}$, 渡辺 一弘 ${ }^{1}$ \\ 1創価大学大学院工学研究科情報システム学専攻 ( \\ 2創価大学大学院 工学研究科生物工学専攻 (†192-8577 東京都八王子市丹木町1-236)
}

\section{Suppressive Effect of Laser Irradiation on the Law of Polar Excitation in Frog Sciatic Nerve}

\author{
Mitsuaki KOMATSU, ${ }^{1}$ Yoshiki MATSUDA, ${ }^{2}$ Yoshio ISHII, ${ }^{1}$ \\ Shinichi KOGURE, ${ }^{2}$ and Kazuhiro WATANABE ${ }^{1}$ \\ ${ }^{1}$ Division of Information Systems Science, Graduate School of Engineering, SOKA University, \\ 1-236 Tangi-cho, Hachioji, Tokyo 192-8577 \\ ${ }^{2}$ Division of Bioengineering, Graduate School of Engineering, SOKA University, \\ 1-236 Tangi-cho, Hachioji, Tokyo 192-8577
}

(Received July 10, 2006)

\begin{abstract}
We examined the effects of $\mathrm{Ar}^{+}$laser $(457,488,514 \mathrm{~nm} ; 25,50,100 \mathrm{~mW})$ irradiation on the law of polar excitation using frog sciatic nerve. The law of polar excitation is well known, as both cathode-make-excitation (CE) and anode-break-excitation (AE) are elicited when nerves are extracellularly stimulated with a longer pulse at suprathreshold intensity. Compound action potentials (CAP) were suppressed by the laser irradiation. Furthermore, the existence of irradiation conditions (power, wavelength) for greatly suppressing AE in comparison with $\mathrm{CE}$ was demonstrated. $\mathrm{Ar}^{+}$laser irradiation did not suppress conduction but did suppress generation of CAP. It seems possible that only AE generation is suppressed by local irradiation using the $\mathrm{Ar}^{+}$laser. Since the contribution of Hyperpolarization-activated channels (Ih) to AE generation had been demonstrated and Ih expression is associated with intractable epilepsy, the present results suggest a novel LLLT for intractable epilepsy as an alternative to Ih blockers.
\end{abstract}

Key Words: Laser irradiation, $\mathrm{Ar}^{+}$laser, Compound Action Potential, Sciatic nerve, The law of polar excitation

1.はじめに

レーザーによる医学治療は，レーザーが発明された当 初から応用分野の一つとして期待されていた。レーザー による治療は非接触治療であるため，ウイルスなどの感 染の危険性が少なく，治療による副作用が起こりにくい ため薬物や手術に制限のある患者にも適用が可能であ り，レーザースポットを絞り込むことにより治療を要す る部位のみの局所的な治療が可能であるなど臨床におい て非常に重要な利点を有する。従来のレーザー治療は レーザーメスのような生体組織の切開，切除を行うもの や網膜剥離の手術に用いる眼底凝固など高密度光パワー を利用したものが主である。

それに対し，組織やタンパク質を変性させない低出力 レーザーには創傷の治癒促進, 疼痛緩和, 抗炎症作用な ど，さまざまな効果が見出されており，臨床で応用され てきた。これらの低出力レーザーによる治療はLLLT(Low reactive Level Laser Therapy：低反応レベルレーザー治療） と呼ばれ，組織反応は生じるが，障害は起こさない治療
である，疼痛の治療を目的とするペインクリニックにお いてもレーザーが用いられており，レーザー治療は従来 の薬剤による治療にみられるような合併症や副作用が少 ないと言われており，他の治療法と比較して有力な治療 手段となりつつある。また，レーザーは光ファイバへの 導波が可能であり，臨床への応用として優れた利点を有 している.

しかし，生体に対する低出力レーザーの作用メカニズ ムについては不明な点が多く, 作用スペクトルも充分に 検討されていない。また，臨床においても医師の経験な どに基づく治療方法が用いられているのが現状である. そのため，安全面への考慮から中枢神経系の疾患治療に は用いられず，末梢神経系の疾患治療にのみ用いられて いるのが現状である。

神経興奮に対するレーザー照射の影響に関して，様々 な実験結果が報告されている。依田らは疼痛物質である ブラジキニンによる刺激応答が低出カレーザー照射 (GaAlAsレーザー 波長 $832 \mathrm{~nm})$ によって可逆的に抑制され ることを明らかにしたが，作用機構の更なる解明には分 
子レベルでの研究が必要であるとしている1,2). 小田-望月 らの研究では，近赤外光レーザー照射によるラット脳組 織内のATP含量の増加が神経活動へ影響を与える可能性を 示唆している3,4). その他, 作用機序は未解明であるもの の，レーザー照射による神経細胞の興奮性の抑制，神経 情報の伝導への影響などが議論されている ${ }^{5-13)}$. 他方, 低 エネルギー量のレーザー照射により神経細胞の興奮性が 上昇する場合や6-8)，レーザー照射による効果はない14)な どの実験結果も報告されている。また，使用するレー ザーの波長としては, 生体に対して比較的高い透過性を 持ち, 散乱の小さい赤色から近赤外の波長が多く使用さ れており，紫から緑の波長帯の可視光はあまり使用され ていない.

そこでレーザー照射を行うための基礎実験として, カ エル坐骨神経標本の光学特性を評価したところ, 吸収率 は可視光領域と比較して近赤外光領域の方が高いという 結果が得られた。このことから, 近赤外光は吸収率が高 く光侵達長が短く, 神経標本に入射した近赤外光の多く は神経標本の表面近傍において吸収されるため, LLLTで 用いられるパワーレベルにおいては神経標本の過度な加 熱や熱蒸散を引き起こす可能性があり，神経細胞を構成 するタンパク質が熱変性する可能性も考えられる.

また，神経細胞を構成するタンパク質は紫外光に対し て大きな吸収特性を持っていることが知られている．紫 外光は光子エネルギーが高く, 生体組織を構成する分子 の主要な結合の解離エネルギーを上回る(光解離蒸散)た め, 紫外光レーザーの生体照射は, 核の遺伝情報の損傷 による発ガン性，ミトコンドリア損傷やアポトーシス発 現による生体毒性も懸念されている.

よって, 紫外光より光子エネルギーが低い可視光を用 いることで無侵襲での実験を行うことが可能であり, 赤 外光より光侵達長が長いため, 比較的低温による実験を 行うことが可能となる.

現在, 神経情報の伝達には神経線維に存在する種々の イオンチャネルが重要な役割を果たしていることが知ら れており，レーザー照射がこれらイオンチャネルに対し て何らかの形で作用しているとされている。しかし，神 経活動におけるイオンチャネルの働きによって発生する 「極興奮の法則」に対してレーザー照射効果の検討を行って いる報告は見受けられない。これまでの筆者らの研究15-17) において，過分極性賦活電流(Ih) 阻害剤であるZD7288を カエル坐骨神経標本に滴下した場合のAEに対する特異的 な抑制効果は可視レーザーを照射した場合のそれと類似 していることが示されている。しかしながら，その原因 については形態学的変化も含めて，いまだ明確ではな い. そこで，本研究では，この「極興奮の法則」に与える影 響について，さらなる検討を加えるために，多波長発振

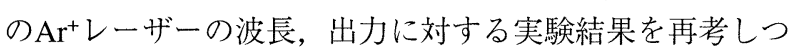
つ，特に神経標本における照射部位の特異性についての 実験的検討を行なっている.さらに, 白色光源を導入し て, 単色性に関する特異性についても比較実験を行なっ た。これにより, 神経活動へのレーザー照射効果のメカ ニズム解明の一助となり，また中枢神経系疾患治療への
応用が可能となると考えられる。

\section{2. 活動電位の測定および実験方法}

\section{1 活動電位の発生原理}

神経線維の一端に矩形パルス電圧発生装置で刺激電圧 (Electrical Stimulation)を与えると, 神経線維のもう一端で は活動電位 (Action Potential) とよばれる電位が測定される (Fig. 1). 活動電位は生体が外界からの刺激を受け，応答 する際に中枢神経と抹梢神経の間で伝達される電気的シ グナルであり, 神経内で出発点から到達点まで同じ大き さで減衰せずに伝達される。

神経線維は原形質膜と呼ばれる膜で覆われており, こ の原形質膜の内外では，外側の基準電極に対して内側が マイナスになるような電位差 (約- 80〜- $70 \mathrm{mV}$ ) が測定さ れる。この電位は膜電位 (Membrane Potential) と呼ばれ, 神経線維が刺激を受けない限りこの電位差は变化しない ので, 静止電位 (Resting Potential) と呼ばれる. 神経線維に 対して矩形パルス電圧発生装置により刺激を与えると静 止電位は変化する。このとき内外の電位差が減少して静 止電位からゼロに近づく方向 (プラス方向)に動くことを脱 分極(Depolarization)といい，逆に電位差がさらに増加しゼ ロから遠ざかる方向(マイナス方向)に動くことを過分極 (Hyperpolarization)という.

Fig. 1 は刺激の大きさに応じて膜電位が変化する様子を 表したものである。ここで, Fig. 1 (a)から (b)のように刺 激電圧の大きさを増加させると, 脱分極のシグナルが起 こり，シグナルの大きさは電圧の大きさに原則として比 例する。しかし, Fig. 1 (c)のように刺激電圧の大きさを さらに大きくした場合, 膜電位がある一定の值に達する と膜電位は急激に上昇し，ゼロを超えてプラス側へ突き

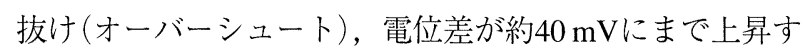
る。その後は緩やかな経過で再び元の静止電位のレベル

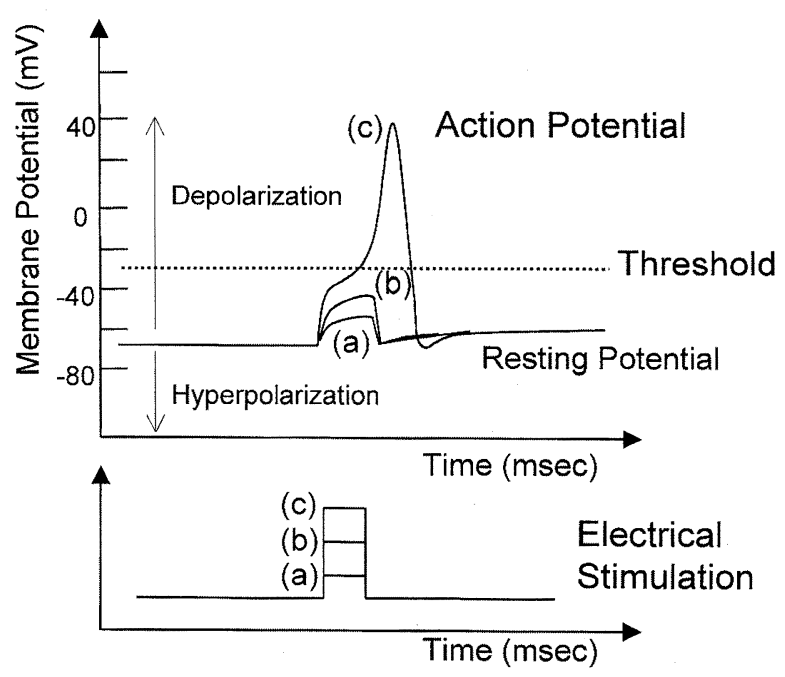

Fig. 1 Waveform of action potential. (a), (b) The membrane potential changes in proportion to stimulus intensity. (c) The membrane potential rapidly rises when it reaches and over the threshold, and gently returns to resting potential afterwards. 
にまで戻る。このような膜電位の応答シグナルが活動電 位である。このように活動電位はニューロンの一部が脱 分極されて一定の值に達することにより発生する。この 一定の脱分極レベルのことをしきい值 (Threshold) と呼 ぶ. 神経線維の内外には $\mathrm{Na}^{+} や \mathrm{~K}^{+}$などのイオンが存在し, 電荷をもったイオンがイオンチャネルと呼ばれる孔を出 入りすることによって膜電位が変化し, 活動電位が発生 する．膜電位がしきい值を越えると $\mathrm{Na}^{+}$チャネルが開孔し 細胞内に $\mathrm{Na}^{+}$が流入 (内向き電流, $\mathrm{Na}^{+}$電流) する。その 後, $\mathrm{K}^{+}$チャネルが開孔し, $\mathrm{K}^{+}$が外部へ流出 (外向き電流, $\mathrm{K}^{+}$電流) し静止電位へと杘る。

実験に用いた神経標本は神経線維の束になっており, 実際に測定される電位は個々の活動電位の合計であり,

これを複合活動電位 (Compound Action Potential: CAP) と呼 ぶ. 全ての神経線維が活動電位を発生する刺激を極大刺 激と呼び，極大刺激を越える大きさの刺激電圧を与えて もCAPの大きさは変化しない。本研究では, このCAPが レーザー照射によってどのように変化するかを検討する ため，極大刺激条件下でのCAPを測定した。

\section{2 極興奮の法則}

神経標本に長い持続 (> $3 \mathrm{msec}$ )のパルス刺激を与える と, 刺激入力時には刺激電極の陰極側で脱分極が起こ り，活動電位発生の原理から興奮性が高まりCAPが発生す る。一方陽極側はパルス刺激の間過分極が起こり，パル 又刺激切断時は脱分極し，CAPが発生する。このとき陰極 側，陽極側で発生する神経の興奮をそれぞれ陰極閉回路 興奮 (cathode make excitation: CE), 陽極開放興奮 (anode break excitation: AE) と呼ぶ. $\mathrm{Na}^{+}$チャネルには不活性化過 程があり，脱分極を与える前に過分極をあらかじめ与え ておくこと(パルス刺激の間の過分極)により, 脱分極(パ ルス刺激切断)による $\mathrm{Na}^{+}$電流が大きくなる。 それは $\mathrm{Na}^{+}$ チャネルの中には静止時でも既に不活性化された状態に あるものが何\%かあり，そのチャネルは脱分極を与える前 の過分極によって解除され活性化準備状態に戻り, 脱分 極により開き得るチャネルの数が増えることによる。し かしFig. 2 (a)のような短いパルス刺激では, 陰極側では 神経の興奮性が高まり, CEが発生するが, 陽極側では過 分極が充分でないため, AEは発生しない. そのため, Fig. 2 (b)のように充分長いパルス刺激を与えることにより， 陰極側だけでなく陽極側も興奮性が高まり，CAPが発生す る.

このように一度の刺激によりCEとAEの二つのCAPが発 生する現象を「極興奮の法則」(law of polar excitation) と呼 ぶ18-20). 本研究では,この「極興奮の法則」におけるCEお よびAEに対するレーザー照射効果について実験を行っ た。

\section{3 実験装置および実験方法}

実験装置の概要をFig. 3に示す。実験標本として体重55 $\sim 80 \mathrm{~g}$ のフリカツメガエル(Xenopus laevis)を使用した。 アフリカツメガエルは水中に生息し，飼育しやすく年間 を通じて産卵させることができるため多くの分野で研究

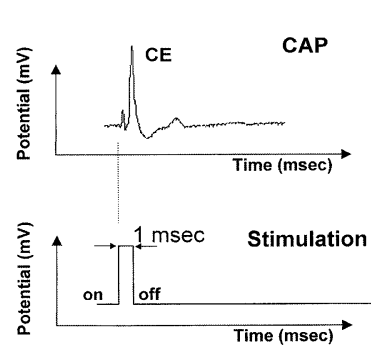

(a) Short pulse

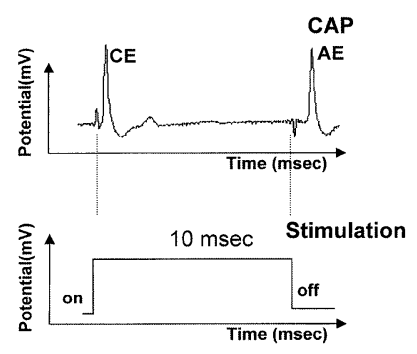

(b) Long pulse
Fig. 2 Schematic diagram of the law of polar excitation. When the sciatic nerve is stimulated by a longer pulse (>3 msec) with supramaximal intensity, CAPs are induced from not only the cathode but also the anode.

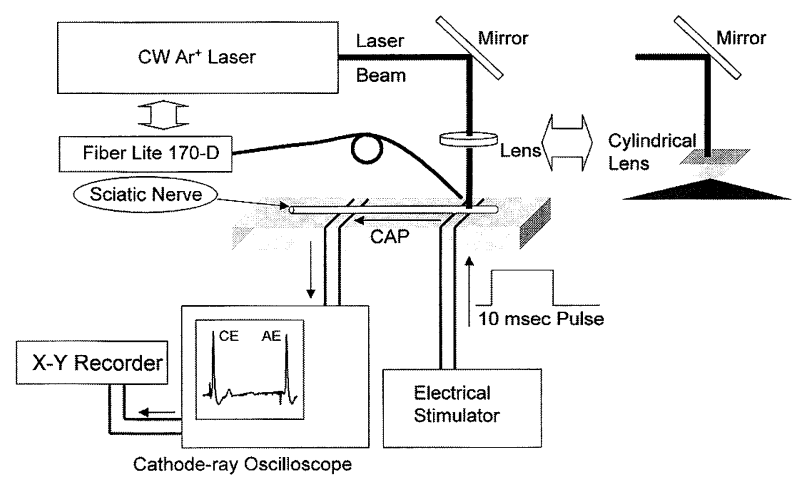

Fig. 3 Schematic diagram of laser and white light irradiation system, including the nerve specimen and CAP measurement system.

材料として使用されている.あらかじめ水水を用いた低 温麻酔でカエルを非動化し, 春髄および脳を破壊し致死 させる。その後リンガー液(生理食塩水)を適宜注ぎながら 解剖を行い, 坐骨神経を脊椎レベルから膝関節部分まで 摘出した。摘出した神経標本を実験装置にセットする. パルス幅 $10 \mathrm{msec} の$ 極大刺激強の電気刺激を発生させ, 神 経標本を刺激することにより「極興奮の法則」が誘発され, CEとAEそれぞれのCAPが神経標本上を伝導し, 記録電極 を介してメモリオシロスコープ上にCAPの波形が映し出さ れる。オシロスコープに映し出された波形はX-Yレコーダ により記録され，CAP振幅を測定する．CAP振幅は個体に より異なるため, この時のCAP振幅を $100 \%$ (Control) とし て標準化し，レーザー照射時間に伴うCAP振幅の変化を測 定した。神経標本をアクリル製の箱により保護すること でレーザー照射実験中の神経標本の乾燥を防いだ。

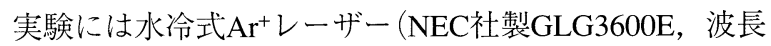
457 $514 \mathrm{~nm}$, 連続発振 $(\mathrm{CW})$, 最大出力 $2 \mathrm{~W}$ )を用い, 照 射パワー，照射波長をさまざま変化させ実験を行い，CAP 振幅に対するレーザー照射効果について検討を行った。

同様の条件で実験を数回繰り返し, 標準化されたCAP 振幅の平均 (mean), 標準誤差 (Standard error of the mean: $\mathrm{SEM})$ を求めた。また，「極興奮の法則」におけるCEと $\mathrm{AE}$ の変化の有意差を検討するため, 2群の平均值の差の検定 を行なうStudentのt検定を用いた。これはCEとAEの変化に 差がないと仮定し(帰無仮説), 帰無仮説が起こりうる確率 
(有意確率：P值)を求めるものである. $\mathrm{P}$ 值が有意水準 $\alpha$ を 下回った場合に帰無仮説は裹却され，CEとAEの変化には 有意差があるとみなすことができる，有意水準 $\alpha$ は $5 \%$ (0.05)に設定するのが一般的である.（後述するが)我々の 研究により AEはてんかん発作波の発現に深く関与してい ることがわかり， $\mathrm{CE}$ と $\mathrm{AE}$ 変化を比較することにより， レーザーによる効果的なてんかん治療を行なう照射条件 を見出すことを目的とする。

\section{3. レーザーおよび白色光源照射による CAPの変化}

はじめに，レーザー照射効果の実験と比較するための 初期条件としてレーザー照射を行わない状態でCAP振幅を $5 \mathrm{~min}$ ごとに30 minまで測定する。その結果， $30 \mathrm{~min}$ 経過 後のCEのCAP振幅は106.6 $\pm 3.1 \%($ mean $\pm \mathrm{SEM}), \mathrm{AE}$ の CAP振幅は105.9 2.2 であり，時間経過におけるCAP振幅 に変化は見られなかった。このことから，摘出した神経 標本は30 minの実験において正常な神経活動を保っている ことが確認された。また，両者間に有意差は認められ ず，CEとAEの変化に差異はみられなかった。

本章では，レーザーの照射パワー，波長，照射位置を 様々に変化させた実験および白色光源照射実験を行い, この実験結果との比較・検討を行った。

\subsection{CAP発生部位へのレーザー照射}

\section{1 .1 照射パワー変化}

実験では，光学ミラーを用いて神経標本に対し垂直に レーザーを照射する，神経標本の太さは個体により異な るため，光学レンズを用いてビーム径を適宜調整する(約 $1.4 \mathrm{~mm})$. 電極径は約 $1 \mathrm{~mm}$ であり，陽極と陰極の間隔は約 $5 \mathrm{~mm}$ である.刺激電極の陰極側から約 $20 \mathrm{~mm}$ の距離に記 録電極の陰極を設置し，さらに間隔5 $\mathrm{mm}$ の位置に記録電 極の陽極を設置した．刺激電極の陽極側と陰極側の中間 に照射位置を設定する，照射波長を514 nmに設定し，照 射パワーを $25 \mathrm{~mW} ， 50 \mathrm{~mW} ， 100 \mathrm{~mW}$ れれぞれの場合に おいてレーザー照射によるCE，AEのCAP振幅の経時変化 を測定した。

実験結果をFig. 4に示す。レーザー照射前のCAP振幅を
$100 \%$ とし，照射時間に対するCAPの変化をCE， $\mathrm{AE}$ れ ぞれについてプロットした. Fig. 4 (a)，（b)，（c)はそれ ぞれ $25 \mathrm{~mW}, 50 \mathrm{~mW}, 100 \mathrm{~mW}$ 照射時の結果を表してい る。照射 $30 \mathrm{~min}$ の時点でのCEと $\mathrm{AE} の \mathrm{CAP}$ 振幅の平均は 25 $\mathrm{mW}$ 照射においてそれぞれ88.4 $19.7 \% ， 76.3 \pm 8.3 \% ， 50$ $\mathrm{mW}$ 照射において $82.3 \pm 4.3 \% ， 72.1 \pm 6.5 \% ， 100 \mathrm{~mW}$ 照射 において $84.7 \pm 12.7 \% ， 75.2 \pm 8.9 \%$ あ゙り，全ての場合 においてレーザー非照射時と比較してCAP振幅の減少が確 認された $(P<0.05)$ ．照射パワーによらずほぼ同程度の抑 制効果が確認された。レーザーによる疼痛緩和効果は, 発痛刺激の減弱，刺激伝達の抑制，下行性抑制系の賦活 により得られるとされており5)，レーザー照射によって CAPが抑制されるということから，痛みなどの神経情報の 伝達がレーザー照射によって抑制されており，本手法に おいても疼痛緩和と同様の効果が得られると考えられ る.

レーザー照射30 minまでの各時間においてCEとAEの有 意差検定を行ったところ， $25 \mathrm{~mW}$ においては照射後 $20 \mathrm{~min}$ から両者間に有意差が認められ $(P<0.05), \mathrm{CE}$ と比較して

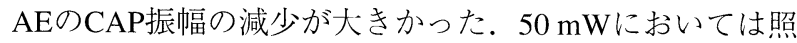
射後 $30 \mathrm{~min}$ において有意差が認められ $(P<0.05), 25 \mathrm{~mW}$ の時と同様にAEのCAP振幅が抑制されていることがわ

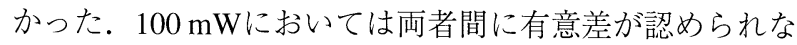
かった.

これらの結果より，レーザー照射による神経活動の抑 制効果は照射パワーに依らず，ほぼ同程度であることが 確認された。また，「極興奮の法則」におけるCEとAEの抑 制効果に対して有意差が認められ，AEが大きく抑制され ていることがわかったが，照射パワーが大きい場合には 有意差が認められなかった。

\section{1 .2 照射波長変化}

3.1.1の実験と同様の実験装置を用いて，波長变化によ るレーザー照射効果について実験を行った，照射パワー は50 mW，波長は457 nm，488 nmに設定し，レーザー照 射方法, 照射位置などは3.1.1と同様の条件で行った。そ れらの結果を3.1.1の波長 $514 \mathrm{~nm}$ ，照射パワー50 mWの実 験結果と比較してFig. 5に示す．Fig. 5 (a)，（b)，（c)はそ れぞれ457 nm, $488 \mathrm{~nm}, 514 \mathrm{~nm}$ 照射時の結果を表す。
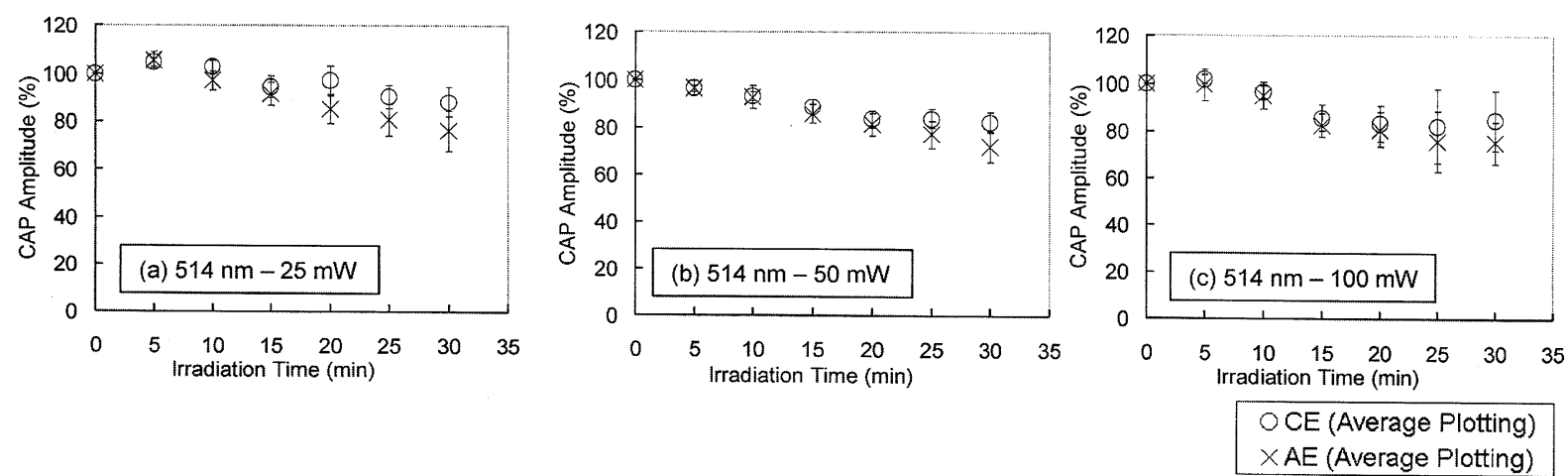

Fig. 4 Results of laser irradiation at 25,50 and $100 \mathrm{~mW}$ using laser at $514 \mathrm{~nm}$ wavelength. Differences between averaged amplitudes of $\mathrm{CE}$ and $\mathrm{AE}$ at $30 \mathrm{~min}$ were significant at $25 \mathrm{~mW}$ and $50 \mathrm{~mW}$. 

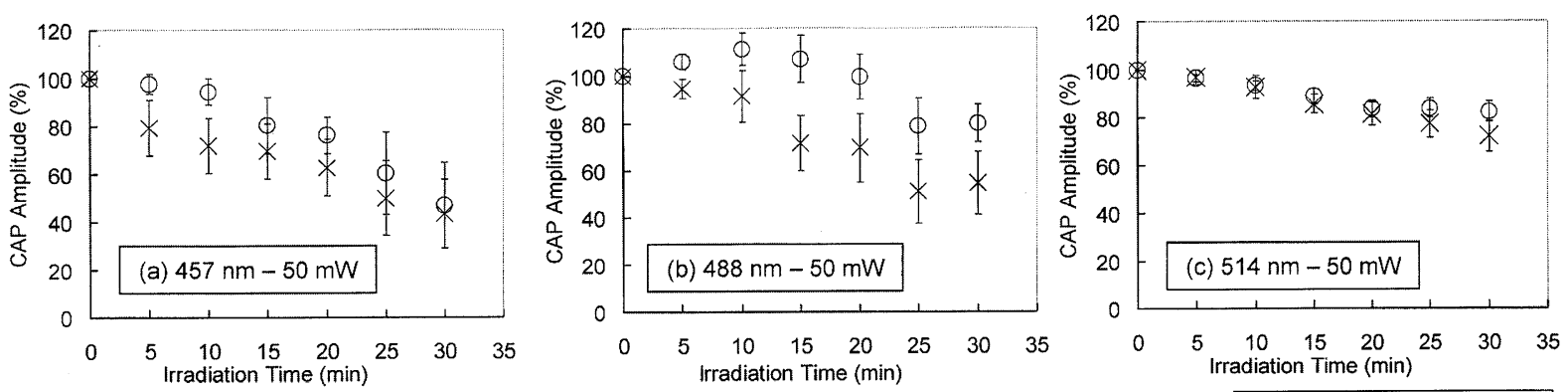

OCE (Average Plotting)

$\times A E$ (Average Plotting)

Fig. 5 Results of laser irradiation at $50 \mathrm{~mW}$ using laser at 457, 488, and $514 \mathrm{~nm}$ wavelengths. Differences between averaged amplitudes of $\mathrm{CE}$ and $\mathrm{AE}$ at $30 \mathrm{~min}$ were significant at $488 \mathrm{~nm}$ wavelength.

実験結果より，457 nm照射における照射 $30 \mathrm{~min}$ でのCE とAEのCAP振幅の平均はそれぞれ $46.8 \pm 17.9 \%, 43.4 \pm$ $14.0 \% ， 488 \mathrm{~nm}$ 照射において79.8 $\pm 7.9 \% ， 54.4 \pm 13.2 \%$, $514 \mathrm{~nm}$ 照射において $82.3 \pm 4.3 \% ， 72.1 \pm 6.5 \%$ あっった。 このことから同一の照射パワーであっても，照射波長を 短波長にすることで神経活動の大きな抑制効果が得られ ることがわかった。

また， $\mathrm{CE}$ とEのCAP振幅の変化を比較したところ，波 長 $457 \mathrm{~nm}$ において有意差は認められなかったが，488 nm の場合において照射 $10 \mathrm{~min}$ から両者間に有意差が認められ $(P<0.01), \mathrm{AE}$ CAP振幅が大きく抑制されていることが わかった。 $514 \mathrm{~nm}$ 照射において有意差が確認されたのは 照射 30 minであり，このことからAEのCAP振幅に対し， より大きな抑制効果を与える波長は $488 \mathrm{~nm}$ であることが 示唆された，2.2で述べたように，「極興奮の法則」におい てCEとAEは異なるメカニズムによって発生しており， $\mathrm{AE}$ の $\mathrm{AP}$ の発生に関与するイオンチャネルの活動に対 し，選択的に抑制効果を与えるレーザー照射条件が存在 することが考えられる。

3.2 神経標本全体へのレーザー照射

前項までの実験では，神経標本に対し電気刺激を付与 している部位，即ちCAPの“発生”部位へのレーザー照射効 果について実験を行った。ここでは，シリンドリカルレ ンズ等の光学系を用いて，神経標本全体(刺激と記録の両 電極間)にレーザーが照射される実験系を構築した。摘出
した神経標本の太さは個体により異なるため, ビーム径 をレンズによって調整し, 神経標本全体にレーザーを照 射した。

CAPの測定は前項までの実験と同様の実験系で行っ た.レーザー照射は波長 $488 \mathrm{~nm}$ において $100 \mathrm{~mW} ， 514 \mathrm{~nm}$ において $25 \mathrm{~mW}$ と $100 \mathrm{~mW} 33$ 通りについて行った。

実験結果をFig. 6に示す. Fig. 6(a)，(b)より $514 \mathrm{~nm}, 100$ $\mathrm{mW}$ の場合の照射 $30 \mathrm{~min}$ における CEと $\mathrm{AE}$ の $\mathrm{CAP}$ 振幅の平 均はそれぞれ $62.1 \pm 17.2 \%, 73.8 \pm 20.1 \%, 488 \mathrm{~nm}, 100$ $\mathrm{mW}$ の場合の照射 $30 \mathrm{~min}$ における CEと $\mathrm{AE} の \mathrm{CAP}$ 振幅の平 均はそれぞれ $54.1 \pm 18.3 \%, 52.5 \pm 7.5$ であり, CAP発生 部位への照射と同様に波長 $488 \mathrm{~nm}$ の場合の方が大きい抑 制効果が得られた。

また, Fig. 6(b)，(c)より, $514 \mathrm{~nm}, 100 \mathrm{~mW}$ 場合の照 射30 minにおける CEと $\mathrm{AE}$ の $\mathrm{CAP}$ 振幅の平均はそれぞれ $62.1 \pm 17.2 \% ， 73.8 \pm 20.1 \%, 514 \mathrm{~nm}, 25 \mathrm{~mW}$ 場合の照 射30 minにおけるCEと AEのCAP振幅の平均はそれぞれ $68.0 \pm 25.4 \% ， 63.6 \pm 34.8 \%$ \%あり，前項までの実験結果 と同様に，照射パワーの変化において抑制効果に差異は みられなかった。

しかし，いずれの場合においても前項での実験結果に みられたような $\mathrm{CE}$ と $\mathrm{AE}$ の抑制効果の有意差は認められな かった $(P>0.05)$. 2.2で述べたようにCEとAEは異なるメ カニズムによっで発生”しているが，発生したCAPの“伝 導”に関してはCEとAEは同様のメカニズムによって伝導 される，神経標本全体へのレーザー照射を行っているた
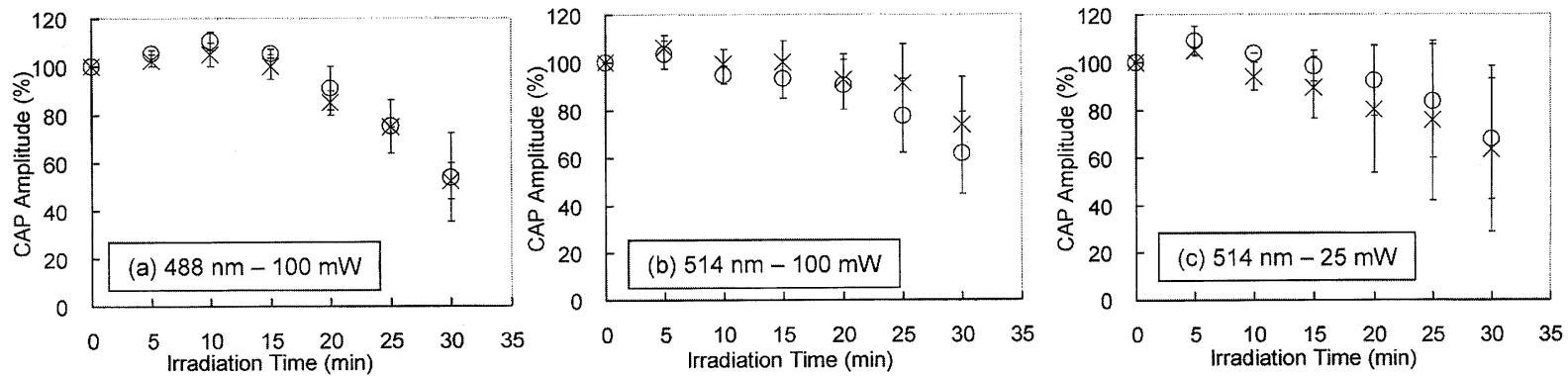

OCE (Average Plotting) $\times$ AE (Average Plotting)

Fig. 6 Results of wide laser irradiation of the nerve specimen. $100 \mathrm{~mW}$ at $488 \mathrm{~nm}$ wavelength and $25 \mathrm{~mW}$, and $100 \mathrm{~mW}$ at $514 \mathrm{~nm}$ wavelength. No significant differences in alterations were identified. 
め，“発生”への影響は少なく，“伝導”への影響が大きいと 考えられ，レーザー照射はAEの“発生”に対して選択的に 抑制効果を与えていることが考えられる.

\subsection{CAP発生部位への白色光源照射}

レーザーの特長である単一波長の優位性を検討するた め, 幅広い波長帯をもつ白色光源を使用し実験を行っ た。実験にはDolan-Jenner社製ファイバ光源Fiber-Lite170Dを使用した．光源ランプにはハロゲンランプ(モデル EKE，150 W，21 V)を使用しており，紫外 $(350 \mathrm{~nm})$ から 赤外 $(1800 \mathrm{~nm})$ までの波長を有し，照射パワーは最大で約 $28 \mathrm{~mW}$ の光源である。実験には約 $7 \mathrm{~mW}$ 照射パワーを用 いた.

3.1の実験方法と同様に，光学系を用いてファイバ光源 を神経標本の太さに合わせて調節し(約 $1.4 \mathrm{~mm}$ )，神経標 本のCAP発生部位に照射し，CAP振幅の測定を同様に行っ た。

実験結果をFig. 7に示す。照射後30 minにおいてCEの

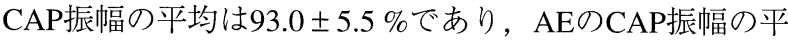
均は67.2 $\pm 11.5 \%$ \%ちった。両者間には統計的有意差は認 められなかった $(P>0.05)$ が，今回使用した光源には3.20 結果で述べたようなAEに対して選択的に作用する波長も 含んでおり，そのためにCEとAEのCAP振幅の変化に差が みられたのではないかと考えられる。

以上のことから，AEのみを選択的に制御するために は，最適な波長を局所的に照射することが必要であり， そのための光源としてレーザーが最適であると結論づけ られる。

\section{4. おわりに}

神経活動における「極興奮の法則」に対するレーザー照 射効果についてカエル坐骨神経標本を用いて，レーザー 照射条件を様々に変化させて実験を行い検討した。

$\mathrm{CAP}$ 発生部位への照射において，照射波長を514 nmに

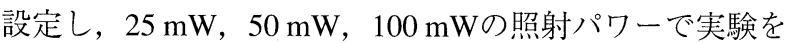
行った結果から，いずれの照射パワーにおいてもCAPの減 弱が確認され，特に $25 \mathrm{~mW} ， 50 \mathrm{~mW}$ 照射においてCEの

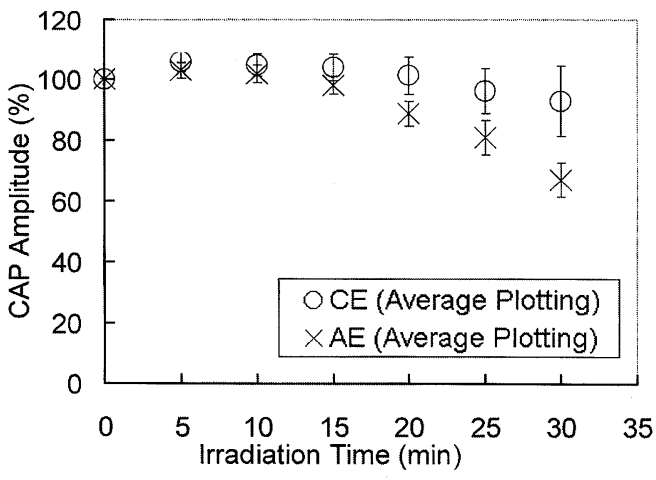

Fig. 7 Results of local white light irradiation using fiber. No significant differences in alterations were identified.
CAP振幅と比較してAEのCAP振幅の減弱が大きく，その 効果に有意差が認められた。同様に，照射波長 $457 \mathrm{~nm}$, $488 \mathrm{~nm} ， 514 \mathrm{~nm}$ において照射パワーを50 mWに設定し実 験を行った結果から，波長 $488 \mathrm{~nm}$ の場合にCEとAEの減弱 に有意差が認められた。このことからAEに対して選択的 に抑制効果を与えるレーザー照射条件が存在することが 示唆された。

また，神経標本全体へのレーザー照射実験の結果から CAPの抑制効果は得られるものの，CEのCAP振幅と $\mathrm{AE} の$ CAP振幅には有意差が認められなかった。よってAEの発 生部位に対してレーザーを照射することにより選択的な 抑制効果が得られる，即ち $\mathrm{AE}$ の“発生”のメカニズムに影 響を与えていることがわかった。

神経標本のCAP発生部位への白色光源照射による実験 においてもCAPの抑制効果は得られたが，CEとAEの有意 差は認められずAEへの選択的な抑制効果は得られなかっ た。

以上のことから「極興奮の法則」におけるAEに対して選 択的に作用する照射条件が存在し，その作用はCAPの“発 生”に対して顕著であるということがわかった。よって最 適な照射波長を用いて，局所的にレーザーをCAP“発生”部

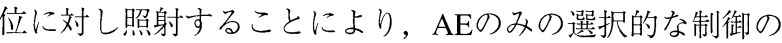
可能性が示唆された。

神経活動に対するレーザー照射効果についてはイオン チャネルへの影響などさまざま議論されている。「極興奮 の法則」におけるCEとAEの興奮性はそれぞれ異なるイオ ンチャネルの働きにより発生する。CEは通常のCAPと同 様に $\mathrm{Na}^{+}$チャネルや $\mathrm{K}^{+}$チャネルにより神経細胞の内外へイ オンが出入りすることにより電位が発生する。しかし, AEは持続的な過分極によって引き起こされるCAPである ことからIhチャネルの関係性が考えられている15-17). Ih チャネルは，心筋細胞で発見され洞房結節のペースメー カ電位発生を担うチャネルとして知られてきたが，近年 の研究において脳内の広い領域で神経細胞膜にも存在す ることが明らかになった。また，てんかん脳においてこ のIhチャネルのはたらきが長期にわたり増強されているこ とが報告され21)，てんかん様発作波の発現に関与してい ると考えられている。

AEに対して大きな抑制効果を示すレーザー照射条件が 存在することは，レーザー照射がIhチャネルに作用してい る可能性を示すものである。今後，さらに研究を進め て，CEには影響を与えずAEのみを効果的に抑制する照射 条件を見出すことができれば，レーザー照射によるてん かん治療にさらに一歩近づくと言える。

\section{謝 辞}

本研究を遂行するにあたり様々な助言を頂いた櫻田 典世博士に深く感謝いたします。また，実験・解析にお いて協力を頂いた岩井 博正氏，本城 信行氏をはじめ研究 室の皆様に感謝の意を表します。 


\section{参考文献}

1) 依田賢太郎：レーザー学会第23回年次大会講演予稿集 (2003) p.220.

2) K. Jimbo, K. Noda, K. Suzuki, and K. Yoda: Neurosci. Lett. 240 (1998) 93.

3) 小田-望月 紀子, 片岡洋佑，崔翼龍，田村泰久，山田久夫 部谷学, 粟津邦男：レーザー研究 30 (2002) 542.

4) 片岡 洋佑：生物物理 41 (2001) 247.

5) 飯島一彦, 下山 直人, 下山恵美, 田村 勝弘：ペインクリ ニック 15 (1994) 827.

6）河谷 正仁，土屋 喜由：ペインクリニック 16 (1995) 533.

7) 亀井 達哉：日本口腔外科学会雑誌 34 (1988) 1584.

8) H. Matsushita, K. Kakami, A. Ito, M. Kaneko, A. Ishihara, K. Yoshida, and M. Fukaya: Aichi-Gakukin Dent Sci. 2 (1989) 19 (in Japanese).

9）前多一雄：歯科放射線 12 (1972) 20

10) Y. Tokita, M. Sunakawa, and H. Suda: Lasers in Surg. Med. 26 (2000) 398.
11) D. W. Ebert and C. Roberts: Lasers in Surg. Med. 21 (1997) 32.

12) R. Orchardson, J. M. Peacock, and C. J. Whitters: J. Dentistry. 26 (1998) 421.

13) U. Wesselmann, S. F. Lin, and W. Z. Rymer: Physiol. Chem. Phys. \& Med. NMR. 23 (1991) 81.

14) U. Comelekoglu, S. Bagis, B. Buyukakilli, G. Sahin, and C. Erdogan: Lasers in Surg. Med. 30 (2002) 221.

15) M. Komatsu, H. Iwai, Y. Ishii, S. Kogure, and K. Watanabe: Proc. The Third Asian Pacific Laser Symposium, (2002). Laser Society of Japan, OSAKA, (2003) p. 638.

16) H. Iwai, M. Komatsu, G. Shiota, N. Honjoe, Y. Kubota, Y. Ishii, K. Watanabe, and S. Kogure: Epilepsia. 46 (2005) 92.

17) Y. Matsuda, M. Niwa, H. Iwai, S. Kogure, N. Honjoe, M. Komatsu, Y. Ishii, and K. Watanabe: Lasers in Surg. Med. 38 (2006) 608.

18) A. L. Hodgkin and A. F. Huxley: J. Physiol. 116 (1952) 497.

19) A. L. Hodgkin and A. F. Huxley: J. Physiol. 117 (1952) 500

20) B. Frankenhaeuser and L. Widen: J. Physiol. 131 (1956) 243.

21) M. Kitayama, H. Miyata, M. Yano, N. Saito, Y. Matsuda, T. Yamauchi, and S. Kogure: Epilepsia 44 (2003) 20. 